УДК 351.713:347.732(477)

\author{
O. П. Федотов
}

\title{
КОНЦЕПЦІЯ ЗДІЙСНЕННЯ ПОСЕРЕДНИЦЬКОЇ ДІЯЛЬНОСТІ У СФЕРІ ДЕРЖАВНОЇ МИТНОЇ СПРАВИ
}

Постановка проблеми. Якісно нове визначення стратегії та тактики розвитку сфери державної митної справи має глобальний характер, адже 3 огляду на важливість інтеграції у світовий торгівельний простір тенденції світового розвитку встановлюють усе нові завдання та вимоги до структурної перебудови та реформування митної галузі. Тому протягом усього періоду розвитку митної справи незалежної України та особливо з виходом українських підприємців на міжнародний ринок науковці та практики митної галузі шукали оптимальну модель функціонування інституту надання посередницьких послуг у сфері державної митної справи відповідно до потреб суб'єктів зовнішньоекономічної діяльності та суспільства в цілому.

Аналіз останніх досліджень і публікацій. Дослідження посереднишької діяльності у сфері державної митної справи здійснювали такі вітчизняні науковці, учені-правознавці та практики митної галузі, як Н.М. Білоусова, В.А. Богатов, К.Г. Борисов, Б.Н. Габричилзе, Ю.М. Дьомін, Є.В. Додін, І.Г. Калєтнік, С.В. Ківалов, Б.А. Кормич, А.В. Мазур, І.В. Міщенко, В.П. Науменко, В.П. Пашко, Д.В. Приймаченко, М.М. Разумей, К.К. Сандровский, Ю.П. Соловков, С.С. Терещенко, В.К. Шкарупа, М.Г. Шульга та інші. Оэнак, враховуючи карэинальні зміни, спричинені процесом активного реформування митної галузі, з'ясування концептуальних засад посередницької діяльності у сфері державної митної справи відіграє досить важливу теоретичну роль.

Виклад основного матеріалу дослідження. Не $\epsilon$ секретом, шо останнім часом (з початку 2005 р. і до сьогодні) було зроблено вагомі кроки щодо спрощення процедур митного контролю та митного оформлення товарів і транспортних засоб́ів комерційного призначення, що перемішуються через митний кордон України, які також знайшли своє відображення i в розробці сприятливих умов здійснення посередницької діяльності у сфері державної митної справи. Господарюючими суб'єктами-підприємствами, які надають посередницькі послуги у сфері державної митної справи 
суб'єктам зовнішньоекономічної діяльності, є підприємства, шо надають послуги з декларування товарів, транспортних засобів комерційного призначення, які перемішуються через митний кордон України, митні склади та склади тимчасового зберігання, вантажні митні комплекси та вільні митні зони комерційного або сервісного типу.

Акцентуючи увагу на збудованій урядом так званій «стратегії спрощення та гармонізації митних процедур», можемо справедливо констатувати, що на сьогодні існує чимало проблем та недоопрацювань, що стосуються організаційно-правових заса」 посередницької діяльності у сфері державної митної справи. На жаль, господарюючі суб'єкти-підприємства, разом із «нечистими на руку» суб'єктами зовнішньоекономічної діяльності стали, так би кажучи, «постійними гостями» на сторінках кримінальної хроніки нашої країни, здійснюючи противоправні діï направлені на зберігання незаконно ввезеної продукції на складських примішеннях митних складів, складів тимчасового зберігання; колосальне та безпідставне підняття грошових ставок на посередницькі послуги у сфері державної митної справи; недотримання термінів повернення валютної виручки (підприємствами, які надають посередницькі послуги у сфері державної митної справи) під час здійснення ними посерејництва в частині експортно-імпортних операцій, пов'язаних із митною галуззю, об' єктом яких $є$ металопродукція, мінеральні добрива, спирт, зерно та інша високоліквідна продукція.

Однак найважливішим питанням, яке стосується посередницької діяльності у сфері державної митної справи, є законодавчо-правова невизначеність та суперечність деяких аспектів функціонування суб́'єктів митного посередництва. Крім того, результати проведення адміністративної реформи в Україні, націленої насамперед на модернізацію інституційної структури та системи органів виконавчої влади та їх персоналу, оптимізацію та формування ефективної системи виконавчої влади, яка функціонуватиме на рівні, що відповідає європейським стандартам, суттєво торкнулися й суб́'єктів зовнішньоекономічної діяльності, і суб́'єктів митного посередництва та умов ї функшіонування.

Так, Митний кодекс України покладає безпосередню реалізацію державної митної справи на фіскальні органи (органи доходів і зборів України), до яких відносить Держану фіскальну службу України, митниці та митні пости (п. 341 ст. 4 Митного кодексу України [9]). Вони і $є$ головними фігурантами державної митної справи поряд із фізичними та юридичними особами, які перемішують товари та транспортні засоби комерційного призначення через митний кордон України. Однак на цьому суб́'єктний склад державної митної справи не закінчується, оскільки останнім часом на митно-правовій арені з'явилося чимало нових учасників - представників сервісної складової державної митної справи. Про неї досить давно зазначав Є.В. Додін, наголошуючи на існуванні такої функції митної справи, як надання послуг [4, с. 7-19]. Мова йде про особливості правового становища категорії суб'єктів, які безпосередньо не беруть участі в зовнішньоекономічних операціях, а надають при цьо- 
му посередницькі послуги імпортерам, експортерам та іншим суб'єктам зовнішньоекономічної діяльності.

На жаль, офішійної назви та визначення ші суб'єкти за досить тривалий час ix існування так і не отримали, хоча чи не кожна зовнішньоекономічна операція супроводжується залученням принаймні олного з них. У процесі ж становлення та розвитку державної митної справи в спеціальній літературі поступово популярності набрав термін «митний посередник».

Крім того, ні Митний кодекс України, ні жоден інший законодавчий та підзаконний нормативний акт не називає повного переліку підприємств, що належать до цієї категорії суб'єктів митної справи. Митний кодекс України лише згадує поняття «посередницький договір», «посередницькі послуги», «посередник», знову ж таки не даючи офіційного тлумачення змісту зазначених категорій.

Слід зазначити, що митні посередники належать до групи суб'єктів митного права, які не мають державно-владних повноважень у сфері державної митної справи та виступають як підлегла сторона [20, с. 33-39]. Аналіз законодавства України з питань державної митної справи дає змогу віднести до цієї категорії таких суб'єктів: митних брокерів, утримувачів складів тимчасового зберігання, а також митних складів відкритого типу, утримувачів вільної митної зони комерційного або сервісного типу та вантажних митних комплексів. Водночас, визначаючи митних посередників як окрему категорію суб'єктів митних правовідносин, слід зазначити, шо такий суб' $€$ кт, як власник магазину безмитної торгівлі також здійснює підприємницьку діяльнність у сфері державної митної справи, і хоча вона фактично не $є$ посередницькою, але у зв'язку 3 тим, що є підприємницькою за своєю природою, ії правове забезпечення здійснюється в розділі XV «Здійснення органами доходів і зборів контролю за окремими видами діяльності» Митного кодексу України [9].

Так, особливим суб'єктом надання послуг у сфері державної митної справи $є$ вантажні митні комплекси, які розпочали свою посередницьку діяльність із надання митних послуг у 1996 р. На сьогодні існуючі вантажні митні комплекси мають між собою суттеві віјмінності, пов'язані 3 технічним, технологічним та організаційним забезпеченням, пропускною спроможністю, кваліфікацією персоналу, задіяному у виконанні обслуговування, тривалістю виконання робіт та іншими важливими для суб'єктів зовнішньоекономічної діяльності факторами.

Кількість вантажних митних комплексів на території України за останні роки різко збільшувалася, шо говорить про зростання попиту на послуги шього об'єкта митної інфраструктури, і мала такі показники: 2010 р. -24 , 2009 p. $-25,2008$ p. $-23,2006$ p. $-17,2005$ p. $-10,2004$ p. $-6[8$, c. $104-$ 107]. Однак відсутність теоретичних передумов вивчення особлиивостей функціонування вантажних митних комплексів та оновлення законодавства України з питань державної митної справи внесли значні корективи в діяльність вантажних митних комплексів як митних посередників.

Так, згідно зі ст. 442 Митного кодексу України, вантажний митний комплекс - це ділянка території з комплексом будівель, споруд, інженер- 
но-технічних засобів і комунікацій, необхідних для здійснення митного контролю та митного оформлення товарів, транспортних засобів комерційного призначення, шо перемішуються через митний кордон України [9].

Функціонування вантажного митного комплексу є підприємницькою діяльністю, яка полягає в створенні сприятливих умов для прискорення товаропотоку через митний кордон України, підгрунтям чого $\varepsilon$ відповідні технічні та технологічні умови, на підставі яких проектується, будується та оснащується вантажний митний комплекс. Його власник виступає сво$\epsilon$ рідним посередником між фіскальним органом (представником держави) та учасниками зовнішньоекономічних операцій.

Законодавством передбачено послуги, які надаються утримувачем вантажного митного комплексу особам, шо перемішують товари через митний кордон України. Зокрема, утримувач вантажного митного комплексу повинен обов'язково забезпечувати такі умови: 1) надання посередницьких послуг із декларування товарів, що перемішуються через митний кордон України; 2) надання послуг зі зберігання товарів, що перемішуються через митний кордон України, і транспортних засобів комерційного призначення; 3) виконання навантажувально-розвантажувальних робіт. На вантажному митному комплексі також можуть бути обладнані місця для надання додаткових послуг [9, ст. 443].

Відповідно до ст. 444 Митного кодексу України взаємовідносини утримувача вантажного митного комплексу з особами, які користуються послугами комплексу, та фіскальними органами визначаються відповідними договорами.

Необхідною умовою для отримання дозволу на відкриття та експлуатацію вантажного митного комплексу $є$ наявність у підприємства дозволу на здійснення митної брокерської діяльності, дозволів на відкриття й експлуатацію складу тимчасового зберігання відкритого типу, а також на відкриття й експлуатацію митного складу відкритого типу [9, ст. 408].

Згідно з п. 3 ст. 406 Митного кодексу Украӥни дозволи на провадження діяльності, пов'язаної з відкриттям та експлуатацією вантажного митного комплексу, надаються митницями, у зонах діяльності яких розташовано відповідні ділянки територій із комплексом будівель, споруд, інженерно-технічних засобів і комунікацій, які можуть використовуватися під час провадження діяльності вантажного митного комплексу, з обов'язковим подальшим повідомленням центрального органу виконавчої влади, що забезпечує реалізацію державної політики у сфері державної митної справи [9].

Одним з обов'язків утримувача вантажного митного комплексу, висвітлених у Митному кодексі України, $є$ забезпечення безоплатного входу та в'їзду на територію комплексу та безоплатного перебування на його території протягом перших чотирьох годин. Однак на сьогодні члени Асоціації міжнародних експедиторів України систематично відчувають труднощі під час проведення митного оформлення вантажів у контейнерах під час перетину кордону в пунктах пропуску, зокрема стосовно питання реалізації положень п. 2 ст. 446 Митного кодексу України щодо обов'язків утри- 
мувача вантажного митного комплексу забезпечити безоплатний вхід та в 'ізд на територію комплексу та безоплатне перебування на його територіі протягом перших чотирьох годин.

Так, наприклад, у зоні діяльності Одеської митниші Державної фіскальної служби України функціонує декілька вантажних митних комплексів, але можливість реалізації положень п. 2 ст. 446 Митного кодексу України, зокрема обов'язків утримувача вантажного митного комплексу забезпечити безоплатний вхід та в'їзд на територію комплексу та безоплатне перебування на його території протягом перших чотирьох годин, відсутня. На нашу думку, положення п. 2 ст. 446 Митного кодексу Украйни має на меті можливість надання безоплатного використання вантажного митного комплексу задля завершення митного оформлення згідно 3 п. 1 ст. 255 Митного кодексу України (протягом чотирьох робочих годин із моменту пред'явлення фіскальному органу товарів [9]), але за фактом суб'єкти, які використовують послуги вантажного митного комплексу, позбавлені можливості використання вантажного митного комплексу протягом перших чотирьох годин на безоплатній основі. У тарифах вантажного митного комплексу передбачено збори під іншим найменуванням, ніж в'їзд та перебування на території вантажного митного комплексу, шо призводить до непередбачених витрат.

Виходом із ситуації, шо склалася, може бути надання Державною фіскальною службою України роз'яснень п. 2 ст. 446 Митного кодексу України та можливості проведення перевірки вантажних митних комплексів щодо дотримання вимог Митного кодексу України.

Говорячи про інститут митних брокерів, необхідно зазначити, що в Україні митні брокери є основним учасником ринку митних послуг. Такі підприємства виконують та здійснюють функції з надання послуг із митного оформлення товарів тим суб́'єктам ЗЕД, які в силу різних причин не мають можливості виконувати митні формальності. Загальним завданням шієї категорії посередників у державній митній справі є професійне здійснювання своєї діяльності на ринку послуг та сприяння зменшенню порушень митних правил. Будучи сполучною ланкою в ланцюгу «суб' $є$ кт зовнішньоекономічної діяльності - фіскальний орган», митні брокери відіграють важливу роль у розвитку зовнішньоекономічної діяльності. При цьому разом із правами, які вони отримують у представленні інтересів клієнтів, ці підприємства повною мірою несуть і відповідальність за прошедуру декларування товарів, передбачену положеннями законодавства України з питань державної митної справи.

На сьогодні митні брокери здійснюють свою діяльність на підставі норм Митного кодексу України від 1 червня 2012 р., наказу Державної фіскальної служби України від 13 сіння 2015 р. № 7 «Про затвердження інформаційних карток адміністративних послуг» та спільного наказу Державної фіскальної служби України та Адміністрації Державної прикордонної служби України від 19 червня 2015 р. № 441/255 АГ «Про надання дозволів на здійснення митної брокерської діяльності» $[9 ; 10 ; 14]$. 
Так, відповідно до положень ст. 416 Митного кодексу України, митний брокер - це підприємство, що надає послуги з декларування товарів, транспортних засобів комершійного призначення, які перемішуються через митний кордон України та провадить митну брокерську діяльність у будь-якому органі доходів і зборів України. За вчинення правопорушень, пов'язаних із провадженням митної брокерської діяльності, митний брокер несе відповідальність, встановлену Митним кодексом України (далі МАК України) та іншими законами України.

Взаємовідносини митного брокера з особою, яку він представляє, визначаються відповідним договором [9, ст. 417]. Отже, митний брокер виконує повноваження в обсязі, встановленому за дорученням особи, яку він представляє, здійснювати будь-які операції, пов'язані з пред'явленням фіскальному органу товарів, транспортних засобів та документів на них до митного оформлення. На практиці між митним брокером та суб'єктом зовнішньоекономічної дія.льності (громадянином) договірні відносини виникають на підставі договору доручення [21, гл. 68].

Необхідно також наголосити на тому, що згідно зі ст. 419 MK України інформація, отримана митним б́рокером чи його працівниками від особи, яку представляє митний брокер, у процесі виконання митних формальностей може використовуватися виключно для цілей виконання цих формальностей. За розголошення інформації, шо становить комерційну таємницю або $€$ конфіденційною, митний брокер та його працівники несуть відповідальність відповідно до закону [9].

Таким чином, можна зазначити, що розвиток інституту митних брокерів в Україні здійснювався досить швидкими темпами. Станом на 28 червня 2015 р. в Україні видано 3859 дозволів на здійснення митної брокерської діяльності [18]. Однак, на жаль, запровадження посередницької діяльності митних брокерів, контроль за якою здійснюють фіскальні органи України, охоплюе широке коло невирішених питань, які належать до компетеншії державної влади. Так, наприклад, досить актуальним на сьогодні $€$ питання потреби або непотрібності механізму впорядкування та можливого коригування митної брокерської діяльності підприємств. Адже відповідно до ст. 7 Закону України «Про ліцензування видів господарської діяльності» від 2 березня 2015 р. № 222-VIII з 00 год. 00 хв. 28 червня 2015 р. піцензування митної брокерської јіяльності припинене, а ліцензії на провадження митної брокерської діяльності вважаються недійсними [5, с. 13]. У свою чергу суб'єкти господарювання, які на дату набрання чинності законом мали чинну лішензію на провадження митної брокерської діяльності, автоматично отримали дозвіл на здійснення цього виду господарської діяльності та включені до реєстру митних брокерів. Однак, з одного боку, будь-який механізм впливу на митну брокерську дія.льність може стримувати розвиток цієї галузі, з іншого - повна безконтрольність або невпорядкованість ринку митних брокерів може дати поштовх до спроб надання недоброякісних послуг.

Посередницька діяльність зі зберігання товарів, транспортних засобів комерційного призначення, шо переміщуються через митний кордон Укра- 
їни, окреслюється, як правило, зберіганням об'єктів матеріального світу, які належать суб'єктам зовнішньоекономічної діяльності на складах тимчасового зберігання та митних складах відкритого типу.

Відповідно до ч. 1 ст. 437 Митного кодексу України, склад тимчасового зберігання - це відповідним чином облаштовані примішення та/або криті чи відкриті майданчики, резервуари, холодильні чи морозильні камери, призначені для тимчасового зберігання товарів під митним контролем до поміщення їх у митний режим. У межах складів тимчасового зберігання та прилеглої до них території утворюються постійні зони митного контролю $[9$, ч. 3 ст. $201 ; 11$, п. 1.4 Положення про склади тимчасового зберігання).

Взаємовідносини утримувача складу тимчасового зберігання відкритого типу з особами, які розмішують товари на цьому складі, визначаються відповідним договором, крім випадків, передбачених Митним кодексом України [9, ст. 438]. Таким договором, як правило, $\epsilon$ јоговір зберігання, у якому визначаються об'єкт зберігання та термін його зберігання.

Утримувач складу тимчасового зберігання створюе належні умови для забезпечення схоронності товарів і транспортних засобів, розміщених на такому складі, відповідно до вимог Митного кодексу України $[11$, п. 1.5].

Отже, основною метою організації та відкриття складів тимчасового зберігання $є$ реалізація положень Митного кодексу України та створення сприятливих умов для проведення процедур митного контролю та митного оформлення товарів і транспортних засобів комерційного призначення, шо перемішуються через митний кордон України.

Склади тимчасового зберігання функціонують відповідно до норм Митного кодексу України і Положення про склади тимчасового зберігання, затвердженого наказом Міністерства фінансів України від 28 травня 2012 р. № 613. Це Положення визначає форму, поряјок подання та розгляду заяв, порядок надання, зупинення діï, анулювання дозволу на відкриття та експлуатацію складу тимчасового зберігання; вимоги до складських об̆'єктів, які можуть використовуватися як склад тимчасового зберігання; правила провадження діяльності складів тимчасового зберігання та порядок контролю за ії провадженням; порядок розміщення, зберігання та обліку товарів, транспортних засобів комерційного призначення на складах тимчасового зберігання [11]

Станом на 1 квітня 2015 р. в Україні видано 386 дозволів на відкриття та експлуатацію складів тимчасового зберігання [16].

Ще одним суб́' $є$ ктом посередницької діяльності у сфері державної митної справи, шо здійснює надання послуг із митного господарювання, $\epsilon$ митний склад. Необхідно відмітити, що в законодавстві України з питань державної митної справи поняття «митний склад» застосовується й для позначення одного з видів митного режиму, відповідно до якого іноземні або українські товари зберігаються під митним контролем з умовним повним звільненням від оподаткування митними платежами та без застосування заходів нетарифного регулювання зовнішньоекономічної діяльності [9, ст. 121]; і для визначення відповідним чином облаштованих складських 
приміщень, резервуарів, холодильних чи морозильних камер, критих чи відкритих майданчиків, призначених для зберігання товарів під митним контролем [9, ч. 1 ст. 424].

На митному складі можуть розмішуватися такі товари: помішені в митний режим митного склалу (у тому числі консолідовані вантажі); помішені в митні режими транзиту, тимчасового ввезення, переробки на митній території, експорту, тимчасового вивезення, переробки за межами митної території (без зміни цих митних режимів на митний режим митного склалу); призначені для тимчасового зберігання під митним контролем (на умовах, встановлених Митним кодексом України для складів тимчасового зберігання).

Як митні склади можуть використовуватися відповідним чином обладнані складські примішення, резервуари, холодильні чи морозильні камери, криті чи відкриті майданчики, призначені для зберігання товарів під митним контролем. Однак посередницька діяльність у цьому випадку має місце тільки за умови функціонування митних складів відкритого типу, які призначено для зберігання під митним контролем товарів, що перемішуються через митний кордон України згідно із зовнішньоекономічними договорами (контрактами), укладеними не тільки утримувачем цього складу, а й будь-якими іншими особами [9, ч. 4 ст. 424], тоді як митний склад закритого типу призначається виключно для зберігання під митним контролем товарів, шо перемішуються через митний кордон України згідно із зовнішньоекономічними договорами (контрактами), що укладаються утримувачем цього складу або учасниками об'єднання підприємств, учасником якого є утримувач складу [9, ч. 4 ст. 424].

Міністерство фінансів України врегулювало порядок відкриття та експлуатації митного складу на підставі відповідного дозволу, який було розроблено на виконання ст. 405 Митного кодексу України. Варто нагадати, шо 3 моменту набрання чинності Митним кодексом України діяльність митних складів майже 2 місяці була «у підвішеному стані», адже правовою підставою для дія.льності таких складів є саме дозвіл, який видається митницею, у зоні діяльності якої розташовано такий склад, однак порядку видачі такого дозволу не було встановлено.

Станом на 1 квітня 2015 р. в Україні видано 287 дозволів на відкриття та експлуатацію митного складу [17].

Традиційно в юридичній літературі висвітлювалась думка про те, шо правовідносини не можуть існувати поза системою права й законодавства, проте, як показує практика, існують випадки, коли прийнято закон, але правовідносини не виникають, оскільки відсутній механізм іх реалізації або не складаються відповідні соціально-економічні умови. Саме такий приклад можна навести у випадку функціонування вільних митних зон комерційного або сервісного типу як митних посередників.

Слід зазначити, що хоча в Митному кодексі України нормами Глави 62 «Відкриття та експлуатація вільної митної зони комерційного або сервісного типу» визначено вільну митну зону як нового суб'єкта митного посере Ј- 
ництва, проте досить довгий час жодного суб'єкта, який би хотів отримати дозвіл на відкриття такої зони не виявлялось із початку вступу в чинність Митного кодексу України [9]. Так, аналіз кількості митних посередників в Україні станом на 1 жовтня 2013 р. дає можливість констатувати відсутність митних правовідносин за участю утримувача ві.льної митної зони за наявності правих норм, що визначали порядок їх діяльності.

Отже, вільна митна зона - це відповідним чином облаштовані територія або склад, що призначені для зберігання товарів під митним контролем, їх переробки та/або виробництва нових товарів. Вільні митні зони можуть бути комерційного, сервісного та промислового типів.

Реалізація законодавства України з питань державної митної справи стосовно вільних митних зон об'єктивно пов'язується насамперед із деталізашією митних процедур, упорядкуванням системи відповідного правового регулювання, належною координацією дій фіскальних і правоохоронних органів, диференціацією самих вільних митних зон залежно від досягнутих економінних показників. Так, наприклад, 4 вересня 2014 р. в межах півострова Крим строком на 10 років було створено вільну економічну зону «Крим» [15]. Згідно із законом на території вільної економічної зони «Крим» діє особливий правовий режим економічної діяльності фізичних та юридичних осіб, у тому числі особливий порядок застосування норм регуляторного, податкового та митного законодавства України, а також особливий режим внутрішньої та зовнішньої міграції фізичних осіб. У межах вільної економічної зони «Крим» створено вільну митну зону, що за своїм функціональним типом $є$ одночасно вільною митною зоною комерційного, сервісного та промислового типу згідно зі ст. 430 Митного кодексу України [9].

Однак створення реальних умов для нормального регулювання посередницького ринку митних послуг, у тому числі тих, які надаються утримувачами вільних митних зон, потребує забезпечення поступового переходу від регулювання цих відносин за допомогою відомчих актів до законодавчого регулювання, яке сприятиме стабільності нормативно-правової бази, усуненню розбіжностей та прогалин у правовому полі, створить умови для розвитку конкуренції в цій сфері, контролю та нагляду за ринком митних послуг із метою створення умов для реалізації прав, свобод, законних інтересів громадян, а також заходів примусового характеру в разі невиконання законодавчих приписів як із боку суб'єктів господарювання, так i фіскальних органів.

Таким чином, дослідивши нормативно-правову базу з питань діяльності зазначених суб' $є$ ктів, можна виділити низку спільних ознак, притаманних усім без винятку митним посередникам, що дасть можливість сформувати уявлення про правовий статус цієї групи суб’єктів та їх місце в реалізації державної митної справи. Так, до загальних ознак можна з упевненістю віднести такі:

1. Митні посередники - це колективні суб'єкти митного права, які є суб'єктами господарювання та частіше за все представлені юридич- 
ними особами та фізичними особами-підприємцями. Цей висновок випливає з положень передусім розділу IV Митного кодексу України, який у ст. 405 визначає види дозвільних документів, шо надаються підприємствам для провадження посереднишької діяльності [9]. Під підприємством Митний кодекс України розуміє будь-яку юридичну особу, а також громадянина-підприємця. Таким чином, у цій якості можуть виступати як фізичні, так і юридичні особи незалежно від форми власності та організаційно-правової форми. Про ці види діяльності має бути зазначено в установчих документах. Утримувачами митних складів можуть бути виключно резиденти $[12$, п. 1.4]. Необхідною умовою для отримання дозволу на вілкриття та експлуатацію вантажного митного комплексу $€$ наявність у підприємства дозволу на здійснення митної брокерської діяльності, дозволів на відкриття та експлуатацію складу тимчасового зберігання відкритого типу та на відкриття та експлуатацію митного складу відкритого типу [9, ч. 1 ст. 408]. Крім того, враховуючи положення П. 1.4 Порядку надання складським об'єктам статусу «митний склад» та позбавлення такого статусу, про які йшлося вище, та той факт, що агентами з митного оформлення, на яких покладено безпосереднє виконання в інтересах особи, яку представляє митний брокер, дій, пов'язаних із пред'явленням фіскальним органам товарів, транспортних засобів комершійного призначення, а також документів, потрібних для здійснення ї митного контролю та митного оформлення, можуть бути тільки фізичні особи-резиденти [9, ч. 1 ст. 418], можна дійти висновку, що утримувачами вантажних митних комплексів також можуть бути тільки резиденти України.

2. Обов'язковою умовою діяльності митних посередників $\epsilon$ необхідність отримання дозвільних документів (дозволів), виданих фіскальними органами за умови виконання визначених законодавством вимог.

3. Митні посередники надають свої послуги на підставі шивільно-правового договору. Так, Митний кодекс України встановлюе, що взаємовідносини митного брокера з особою, яку він представляє, утримувача митного складу відкритого типу з особами, які розміщують товари на цьому складі, утримувача складу тимчасового зберігання відкритого типу з особами, які розмішують товари на цьому складі, утримувача вантажного митного комплексу з особами, які користуються послугами комплексу, та органами доходів і зборів визначаються відповідними договорами [9, ч. 1 ст. 417, ч. 1 ст. 425 , ч. 1 ст. 438, ч. 1 ст. 444].

4. Надаючи на договірних засадах послуги у сфері державної митної справи, митні посередники в цей же час вступають у правовідносини з фіскальними органами. Ці правовідносини досить різноманітні, мають різне змістовне наповнення. Так, прикладом таких відносин може служити взаємодія цих суб'єктів у формуванні відповідних реєстрів митних посередників, знову ж таки в процесі видачі, переоформлення, анулювання дозвільних документів, контролю за їх діяльністю тошо. Цілком погоджуємося з твердженням, що відносини, які виникають між митними 
посередниками та фіскальними органами України, за правовою природою можна визначити як адміністративно-правові вертикального виду. Саме ші відносини, шо характеризуються наявністю в однієі сторони державно-владних повноважень (фіскальні органи) шодо другої сторони відносин (митні посередники), найяскравіше вияв.яють сутність адміністративно-правового регулювання. Для таких відносин характерні нерівність сторін, підлеглість однієї сторони іншій, наявність організаційної підпорядкованості та їі відсутність; підконтрольність і піднаглядність, нерівність сторін у юридичному розумінні [19, с. 194-199].

5. Регулювання діяльності митних посередників здійснюється нормами законодавства України з питань державної митної справи та цивільно-правовим договором відповідного типу. Серед актів законодавства України з питань державної митної справи провідне місце займає Митний кодекс України, який більшою чи меншою мірою, переважно в загальних рисах, регулює відносини за участю кожного з митних посередників. Крім того, щодо кожного з них прийнято відповідне положення, яке затверджено наказом Міністерства фінансів України.

Висновки. Таким чином, митні посередники - це підприємства, які на підставі цивільного-правового договору певного виду та дозвільних документів надають з ініціативи суб'єктів зовнішньоекономічної діяльності, які перемішують товари та транспортні засоби комершійного призначення через митний кордон України, посерејнишькі послуги, спрямовані на реалізацію їхніх прав і свобод у сфері державної митної справи та представлення їх інтересів у фіскальних органах України.

Як інтегруючий елемент посередницької діяльності в реалізації державної митної справи можна виділити посередницьку функцію, яка виконується всіма суб'єктами цієї категорії. Крім того, не слід забувати й про комерційний ефект від цієї діяльності, який без перебільшення $\epsilon$ рушійною силою розвитку шього напряму державної митної справи України.

Якщо $з$ останнім твердженням усе зрозуміло, то стосовно посередницької функції можуть виникати питання та суперечки. Сутність посередницької діяльності в загальному розумінні полягає в діяльності посередника щодо реалізації повноважень в інтересах їх установника [2, с. 89-97]. Поняття комерційного посередництва, яким власне є діяльність означених вище суб́' $є$ ктів, містить ч. 1 ст. 295 Господарського кодексу України, згідно з якою комершійним посередництвом $є$ різновид підприємнишької діяльності, шо полягає в наданні комерційним агентом послуг суб' $€$ ктам господарювання під час здійснення ними господарської діяльності шляхом посередництва від імені, в інтересах, під контролем і за рахунок суб'єкта, якого він представляє [3]. Це визначення зазнало жорсткої критики в цивілістичній літературі через те, що український законодавець став на шлях обмеженого тлумачення терміна «посередництво» і розуміє під ним лише надання фактичних послуг [7, с. 65-71]. Зважаючи на те, що діяльність митних посередників знаходиться пе- 
реважно в митно-правовій плошині, для характеристики ї сутності достатньо зрозуміти основну ідею посередництва: це діяльність третіх осіб, спрямована на оптимізашію, прискорення та підвишення ефективності правових зв'язків між сторонами правовідношення (у нашому випадку між суб'єктом зовнішньоекономічної діяльності та фіскальним органом), а також основний його принцип: право власності на товар не переходить до посередника в результаті його діяльності. У загальному розумінні митним посередництвом $є$ підприємницька діяльність третіх осіб, яку спрямовано на оптимізацію, підвишення ефективності право-

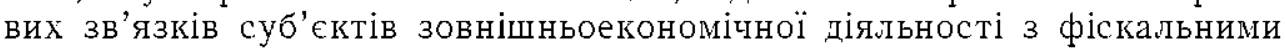
органами. Зважаючи на те, що особи, які іiі здійснюють, вступають у правовідносини не тільки зі своїми клієнтами, а й із фіскальними органами, ця діяльність входить до змісту державної митної справи, однак вторинно, опосередковано. Адже теоретично без зазначених суб'єктів реалізація державної митної справи не припинилася б, однак на практиці без митних посередників важко уявити навіть найпростішу зовнішньоторговельну операцію.

Отже, специфіка правового статусу суб'єктів, шо здійснюють посередницьку діяльність у сфері державної митної справи, пояснюється передусім дуалізмом іï регулювання, який формує неоднозначне становише цих суб'єктів: одночасно вони виступають як суб'єкти митного та цивільного права з усіма притаманними їм ознаками. 3 іншого боку, саме такий подвійний вплив на митних посередників дає змогу віднайти баланс між вільним волевиявленням учасника договірних відносин та субординацією, імперативністю та суворою регламентацією діяльності суб'єкта публічно-правової галузі, від чого, на наш погляд, він лише виграє.

На нашу думку, необхідним $є$ визначення понять «митна посередницька діяльність» $\mathrm{i}$ «митний посередник» як законодавчих термінів у Митному кодексі України. Розширення митної термінології цими одиницями сприятиме більш чіткому правому регулюванню митних правові.носин за участю митних посередників, а також розумінню законодавчих норм, що стосуються діяльності митних посередників.

Крім того, залишається невирішеним питання монополізації деяких видів діяльності певними видами підприємств, шо здійснюють господарську діяльність у сфері державної митної справи на ринку утримувачів вантажних митних комплексів або монополізашії банківськими установами та фінансовими посередниками ринку з надання фінансових гарантій забезпечення виконання зобов'язань перед митницями.

Визначення суб'єктного складу митних правовідносин за участю митних посередників має важливе значення як для теоретичного осмислення митних правовідносин та їх особливостей як явища, що розвивається, так і для практики митного регулювання з метою ефективного правового впливу на суб'єктів митного посередництва. Подальші напрями досліджень митних посередників як учасників митних правовідносин 
має бути спрямовано в плошину реалізації правового статусу митних посередників у сучасних умовах.

\section{Лiтература:}

1. Бондаренко Т.О. Правові та організаційні аспекти функціонування мнтних ліцензійних складів / I.О. Бондаренко / / Митна справа. - 2005. - № 4. - С. 29-33.

2. Васильєва В.А. Повноваження як видоутворюючий критерій посередницьких зобов'язань / В.А. Васильєва // Вісник Академії правових наук України. - 2005. - № 1. - С. 89-97.

3. Господарський Кодекс України : Закон Українн від 16 січня 2003 р. № 436-IV / / Відомості Верховної Ради Українн. - 2003. - № 18. - Ст.144.

4. Додін Є.В. Функції і форми діяльності митних органів України / Є.В. Додін // Митна справа. - № 5. - 2003. - C. 7-19.

5. Карцева Я.М. Митні склади тепер офіційно з дозволом / Я.М. Карцева [Електронний pecypcl. - Режнм доступу : http:/ /www.legalalliance.com.ua/ukr/press/1903.

6. Колосов P.B. Поняття «Посередництво» у законодавстві та доктрнні цивільного та господарського права: порівняльно-правовий аспект / Р.В. Колосов // Бюлетень Міністерства юстиції Утраїни. - 2009. - № 3. - С. 65-71.

7. Коцюк О.Я. Дослідження діяльності вантажних митних комплексів при виконанні міжнародннх автомобі.льних перевезень / О.Я. Коцюк, Н.О. Лужанська / / Управління проектамн, снстемний аналіз і логістика. Технічна серія. - 2011. - Внп. 8. - С. 104-107.

8. Митний кодекс України : Закон України від 13 березня 2012 р. № 4495-VI / / Урядовий кур'єр. - 2012. - № 86. - С. 9-26.

9. Про затвердження інформаційних карток адміністративних послуг : наказ Державної фіскальної служби України від 13 січня 2015 р. № 7.

10. Про затвердження Положення про складн тимчасового зберігання: Наказ Міністерства фінансів України від 28 травня 2012 р. № 613 // Офіційний вісник Украйни. - 2012. № 62. - Ст. 2552.

11. Про затвердження Порядку надання складським об'єктам статусу «митний склад» та позбавлення такого статусу : Наказ Міністерства фінансів України від 16 липня 2012 р. № 835 / / Офіційннй вісннк України. - 2012. - Jo6 61. - Ст. 2491.

12. Про надання дозволів на здійснення митної брокерсыкої діяльності : наказ Державної фіскальної служби України та Адміністрації Державної прикордонної служби України від 19 червня 2015 р. № $441 / 255$ АГ [Електронний ресурс]. - Режим доступу : http:/ / www. mdoffice.com.ua / pls / MDOffice /aSNewsDic.getNews?dat $=24062015 \&$ \&um_c $=484441$.

13. Про створення вільної економічної зони «Крнм» і про особ.ливості здійснення економічної діяльності на тимчасово окупованій території України : Закон України від 12 серпня 2014 р. № 1636-VII / / Офіційний вісник України. - 2014. - № 78. - Ст. 2222.

14. Реєстр підприємств, яким надано дозвіл на провадження митної брокерсыкої діяльності ГЕлектронний ресурсl. - Режим доступу : http://sis.gov.ua/dovidniki--reestri--perelik/ reestri/94921.html.

15. Реєстр підприємств, яким надано дозвіл на відкриття та експлуатацію складу тимчасового зберігання [Електронний ресурс]. - Режим доступу : http://sfs.gov.ua/dovidniki-reestri-. perelik/reestri/94919.html.

16. Реєстр підприємств, яким надано дозвіл на відкриття та експлуатацію митного скиаду |Електронний ресурс|. - Режим доступу : http://sis.gov.ua/dovidniki--reestri--perelik/ reestri/94929.html.

17. Світлак I.I. Взаємодія митних брокерів та митних перевізників з митними органами України / I.I. Світлак // Науковий вісник Національної академії ДПС Утраїни. - 2004. - № 5. C. $194-199$

18. Федотова І.О. Суб́єкти митного права / Т.О. Федотова // Митна справа. - 2011. No $5 .-$ C. $33-39$

19. Цивільний кодекс України : Закон України від 16 січня 2003 р. № 435-IV / / Голос України. -2003 . - № 45 . 


\section{Анот а ція}

Федотов О. П. Концепція здійснення посередницької діяльності у сфері державної митної справи. - Стаття.

У статті на основі аналізу чинного законодавства України розкрито зміст та сутність посередницької діяльності у сфері державної митної справи. Надано авторське визначення поняття «митний посередник». Встановлено, що на сьогодні існус чимало проблем та недоопрацювань, що стосуються організаційно-правових засад посередницької діяльності у сфері державної мит ної справи. Акцентовано увагу на тому факті, що найважливішим питанням, яке стосується посередницької діяльності у сфері державної митної справи, $€$ законодавчо-правова невизначеність та суперечність деяких аспектів функціонування суб'сктів митного посередництва. Обıрунтовано той факт, що до категорії митних посередників можливо віднести митних борокерів. утримувачів складів тимчасового зберігання, а також митних складів відкритого типу, утримувачів вільної митної зони комерційного або сервісного типу та вантажних митних комплексів. Водночас такий суб'єкт, як власник магазину безмитної торгівлі здійснює підприємницьку діяльність у сфері державної митної справи, хоча вона фактично не с посередницькою.

Клюtosi 'лова: державна митна справа, посередницькі послуги, митні послуги, мит. ний посередник, митний брокер, вантажний митний комплекс, вільна митна зона, митний склад, склад тимчасового зберігання.

\section{Ан но т а и я}

Федотов A. П. Концепция осуществления посреднической деятельности в сфере государственного таможенного дела. - Статья.

В статье на основе анализа действующего законодательства Украины раскрыто содержание и суцность посреднической деятельнности в сфере государственного таможенного дела. Предоставлено авторское определение понятия "таможенный посредник». Установлено, что на сегодняшний день существует немало проблем и недоработок, касающихся организационно-правовых основ посреднической деятельности в сфере государственного таможенного дела. Акцентировано внимание на том факте, что важнейшим вопросом, касаюшимся посреднической деятельности в сфере государственного таможенного дела, является законодательно-правовая неопределенность и противоречивость некоторых аспектов функционирования субъектов таможенного посредничества. Обоснованно тот факт, что к категории таможенныХ посредников можно отнести таможенных брокеров, держателей складов временного хранения, а также таможенных складов открытого типа, держателей свободной таможенной зоны коммерческого или сервисного типа и грузовых таможенных комплексов. В то же время такой субъект, как владелец магазина беспошлинной торговли осушествляет предпринимательскую деятельность в сфере государственного таможенного дела, однако она фактически не является посреднической.

Kaloteble lлoвa: государственное таможенное дело, посреднические услуги, таможенные услуги, таможенный посредник, таможенный брокер, грузовой таможенный комплекс, свободная таможенная зона, таможенный склад. склад временного хранения.

\section{Su m m a r y}

Fedotoo $\boldsymbol{O}$.P. The concept of carrying out agency work in the sphere of state customs business. - Article.

The essence and content of agency work in the sphere of state customs business has been shown in the article on the ground of analyzing the effective legislation of Ukraine. Author's definition of the notion "customs clearance agent" has been provided. It has been determined that at present there are rather many problems and shortcomings regarding organizational and legal principles of agency work in the sphere of state customs business. The attention has been drawn to the lact that the most significant issue concerning agency work in the sphere of state customs business is legislative and legal uncertainty and divergence of some aspects of functioning of subjects of foreign economic activity. We have grounded the fact that customs brokers, temporary storage warehouse keepers, as well as open customs warehouse keepers, keepers of free customs zone of commercial or service type and freight customs complexes can be attributed to the category of customs agents. At the same time such subject as owner of duty-free shop carries out entrepreneurial activity in the sphere of state customs business, although it is not actually agency activity.

Kety worls: state customs business, agency work, customs services, customs agent, customs broker, freight customs complex, free customs zone, customs warehouse, temporary storage warehouse. 